\title{
The commodity systems of four indigenous leafy vegetables in Senegal ${ }^{\#}$
}

\author{
Meïssa Diouf ${ }^{1}$, M Gueye $^{2}$, B Faye ${ }^{1}$, O Dieme ${ }^{3}$ and C Lo ${ }^{1}$ \\ ${ }^{1}$ Institut Sénégalais de Recherches Agricoles (ISRA), Senegal \\ ${ }^{2}$ Institut Fondamental d'Afrique Noire Cheikh Anta DIOP, Senegal \\ ${ }^{3}$ Institut de Technologie Alimentaire (ITA), Senegal
}

\begin{abstract}
Increasing the production of traditional leafy vegetables that are well adapted to the agro-ecology of Senegal, easy to grow and requiring low inputs, could greatly help to solve the poverty and malnutrition problems in Senegal. However, leafy vegetables are often overlooked by the scientific community. The species of leafy vegetables dealt with in this paper are roselle (Hibiscus sabdariffa L.), cowpea (Vigna unguiculata (L.) Walp), amaranths (Amaranthus L. spp.) and Moringa (Moringa oleifera Lam). To increase production of traditional leafy vegetables, access to good quality seeds is necessary. Two plantcollecting missions were undertaken throughout Senegal by a multidisciplinary research team. Experimentation on Hibiscus regeneration and characterisation was conducted at ISRA-CDH research station. Sixty-four accessions were collected among the four species. Forty-eight accessions of roselle (Hibiscus sabdariffa L.) were characterised. The level of dissimilarity (63\%) within the accessions of roselle confirmed the high degree of intra-species variability. The Richness Index determined for the Diaobe and Matam markets indicated a high degree of genetic diversity of roselle. These are used to select three new lines according to farmers' preference criteria.

In addition, socio-economic surveys were conducted in two pilot villages. It was found that planting dates for leafy vegetables varied greatly, depending on species, locality and season. Sowing was mainly done broadcast. Organic fertilisers were commonly applied. Eighty per cent (80\%) of the farmers applied an NPK formulation and small quantities of urea. Traditional irrigation methods are often used in the growing of traditional leafy vegetables. The seeds used by farmers were a mixture of varieties. Farmers identified four types of each of roselle, amaranth and cowpea, but could not differentiate any variety for Moringa. Local markets constitute the main roselle seed supply source. Few farmers have developed traditional methods of seed conservation. Selling of seed is not a common activity in rural areas. Generally, farmers exchange gratuitously theirs seeds. Leaves are commonly sold at the field, in the village, in the nearest city and weekly at local markets called 'Louma'. Average annual income generated by leaves varies from 41 to 500 USD. Leafy vegetables are used as food and for medicinal purposes. Leafy vegetable consumption in Senegal is around $23 \mathrm{~g} / \mathrm{person} \cdot \mathrm{d}$.
\end{abstract}

Keywords: leafy vegetables, production, species, seed and genetic diversity

\section{Introduction}

With the Senegalese population increasing at a rate of $2.7 \%$ per year and poverty on the rise in rural and peri-urban areas, malnutrition is becoming increasingly endemic. Fifty-four per cent (54\%) of the households in Senegal live under the threshold of poverty (Quid, 2001). It is estimated that by the year 2015, half of the population will still be in the same situation. Women and children living in rural areas are the most vulnerable groups. Increasing the production of traditional leafy vegetables that are well adapted to the agro-ecology of Senegal and that are easy to grow and require low inputs, could greatly help to solve the malnutrition problem. When the capacity of these leafy vegetables to produce high yields and their relatively short growing periods, as compared to cereals are taken into account, their potential to play a key role in fighting hunger in highly populated countries becomes evident (Watson and Eyzaguire, 2002). However, leafy vegetables are often overlooked by the scientific and development community (Westphal et al., 1987).

\# Revised version. Originally presented at the International Symposium on the Nutritional Value and Water Use of Indigenous Crops for Improved Livelihoods held on 19 and 20 September 2006 at the University of Pretoria in Pretoria, South Africa

* To whom all correspondence should be addressed.

Fax: +221 8350610; e-mail: dmeissa@yahoo.com
Previous studies have shown that traditional leafy vegetables are richer in vitamins, mineral elements and crude fibres than European vegetables (Chadha et al., 2000). In order to increase production of traditional leafy vegetables, access to good quality seeds is necessary, and different vegetables need to be grown during the most suitable season for each. To make good quality seed available, effective germ-plasm management of the priority species is crucial. This requires the establishment of good collaboration with farmers who have a rich experience in biodiversity management of these species (Joshi et al., 1996). The species of leafy vegetables dealt with in this paper are roselle (Hibiscus sabdariffa L.), cowpea (Vigna unguiculata (L.) Walp), amaranths (Amaranthus L. spp) and Moringa (Moringa oleifera Lam). Diouf et al. (1999) reported on the socio-economic importance of these species in Senegal. This paper reports on farmers' systems of production, the taxonomy of the local varieties, the various uses of the vegetables, and the agro-morphological characterisation of Hibiscus accessions.

\section{Materials and methods}

Two collecting missions were undertaken throughout Senegal by a multidisciplinary research team during the dry season (June 2002 and March 2003). Seven regions were selected, based on the results of a previous survey (Diouf et al., 1999). The herbarium of the Cheikh Anta Diop University in Dakar was visited. 
Socio-economic surveys, using tools of the Participatory Rural Appraisal (PRA) approach (Ellsworth, 1992), were conducted in two pilot villages. Socio-economic surveys took 8d and collecting missions 10d. In situ or ex situ germ-plam conservation needs multiplication and characterisation of seeds collected. Accessions of Hibiscus received priority. Forty-eight accessions of roselle (Hibiscus sabdariffa L.), the most widely used species of leafy vegetable in Senegal, were characterised and three new lines selected, using farmers' preference criteria.

Field experimentation was conducted at ISRA-CDH research station, using a random plot experimental design (IPGRI, 2001). Cultural practices were followed in terms of the guidelines of Beniest (1987) for Hibiscus. A simplified version of Bricage's methodology for Hibiscus chracterisation was used (Bricage, 1978). The most common varieties (Vcdh, Vimto, and Koor) were used as controls during the experiments.

Many parameters (plant height, canopy, flowers, leaf and seed production, etc.) were recorded on samples of five plants each. In total 11 parameters were recorded on each plant of the 48 accessions of Hibiscus.

All the data were entered into EXCEL Logicial. Data in percentage were transformed using angular transformation (Arc sinus $\sqrt{x}$ ) before their introduction into multivariate statistical analysis using R Logicial (Gentleman and Ihaka, 2002). Genetic diversity was evaluated using Richness Index (Grum, 2002) as criterion.

\section{Results and discussion}

\section{Collecting and survey missions}

Sixty-four accessions were collected in the field, and 101 accessions were inventoried in the herbariums of IFAN and the Department of Plant Biology of Cheikh Anta Diop University in Dakar. Among these 101 accessions, 54 were collected in Senegal and 47 in neighbouring countries. From these results the following conclusions could be drawn: Hibiscus sabdariffa is the most widely spread leafy vegetable in Senegal. Moringa oleifera and Amaranthus viridis are also widely spread in Senegal and the neighbouring countries. These results confirmed the findings obtained by Diouf et al. (1999).

\section{Production}

Planting dates used for leafy vegetables varied greatly, depending on the species, the locality and the season. However, October and December (autumn and winter) were the most common sowing months. Sowing was mainly done broadcast, but sometimes in rows or furrows. Spacing of $15-20 \mathrm{~cm}$ within rows and $10-15 \mathrm{~cm}$ between rows was commonly used. Sowing rates ranged from $15-25 \mathrm{~kg} / \mathrm{ha}$ for roselle, which is much higher than the rate (4-8 kg/ha) recommended by research (Beniest, 1987). Thinning was done only for roselle. The young plants that were removed during thinning were sold on the market, whilst the remaining plants were left until full development of the branches. Thinning started 4 weeks after sowing and ended with full development of the secondary branches.

Organic fertilisers were commonly applied. Cattle, goat, sheep and chicken manure were mainly used. Eighty per cent of the farmers also applied NPK formulation (10-10-20), but at lower rates than the $900 \mathrm{~kg} / \mathrm{ha}$ recommended by research (Beniest, 1987). Small quantities of urea are applied after each harvest.

Traditional leafy vegetables were often grown under irrigation, using traditional irrigation methods, such as watering cans, bowls, calabashes and buckets. Sometimes furrow irrigation was applied. Some farmers produced leafy vegetables rain-fed during the rainy season, i.e. without applying irrigation.

Insects and other pests are important problems in leafy vegetable production. The most important insects are caterpillars, bite and suckering insects, etc. Rodents and grasshoppers are the most common pests. Chemical spraying was only done on single crops. However, most producers cannot properly identify the responsible pests and appropriate control methods are not well known.

Harvesting leaves of roselle, cowpea or amaranth starts 15 to $30 \mathrm{~d}$ after sowing. The production of harvestable leaves of these species for a single crop can last for 3 to 12 months. Roselle leaves can be kept fresh for 2 to $4 \mathrm{~d}$ after harvesting if they are placed in a wet fibre bag and stored in a cool room. Moringa and amaranth leaves are stored after sun drying. Most of the producers do not know what their mean annual production is but they know the average annual income generated by leafy vegetable production. In some areas of Senegal leafy vegetables are harvested in the wild.

Non-availability of high quality seeds, poor control of pests and diseases, lack of improved cultural practices and lack of effective technologies for post-harvest preservation and processing of leaves were found to be the main constraints to successful production of traditional leafy vegetables.

\section{Varieties and local taxonomy}

The seeds used by farmers were a mixture of varieties. Farmers identified four types of each of roselle, amaranth and cowpea (Table 1). The characteristics used to identify the varieties of roselle are the colour, size and shape of the leaves, the presence or absence of leaf lobs and occasionally the seed colour. Among the four types of roselle, two have green and two red leaves. The two green ones are named Mame Diarra and Bambara and the two red ones named Ordinaire or Koor and Vimto. Mame Diarra and Bambara varieties both have green leaves and calyx, but the leaves of Mame Diarra are lobeless, while those of Bambara are deeply lobed and it is sometimes called five fingers. The variety Ordinaire or Koor has red calyx and red veined leaves, while Vimto has red-purple veined leaves and calyx. For use as leafy vegetables, Mame Diarra and Bambara are preferred by all ethnic groups in Senegal. Only when these two green varieties are not available on the market will consumers buy the red varieties.

In terms of grain colour, the four varieties of cowpea consisted of one red, one white, one black and one mixed black-andwhite variety. The varieties producing broad leaves were considered best by consumers. For amaranth, there was a variety with narrow light green leaves, one with broad light green leaves, one with dark green leaves and one with red leaves. The varieties with broad leaves were preferred by consumers. Farmers were unable to distinguish between different varieties of Moringa oleifera.

\section{Seed production and conservation}

The market is the main source of roselle seed. Retailers collect the seeds from local production that is done during rainy season around the fields of main crops like pearl millet and peanuts. Self-production of roselle seed is widely done by farmers. The farmers leave few plants at random in the field without any criteria of selection and any respect of isolation distance to avoid cross-pollination. Generally high quality seed supply is a big constraint in leafy vegetable production. 


\begin{tabular}{|l|l|l|}
\hline \multicolumn{3}{|c|}{$\begin{array}{r}\text { TABLE } 1 \\
\text { Species, local taxonomy (variety names) and characteristics of the most } \\
\text { common leafy vegetables found and produced in Senegal }\end{array}$} \\
\hline Species & Variety names & Characteristics \\
\hline Hibiscus sabdariffa L. & Mame Diarra & Entire green leaves and green calyx \\
\cline { 2 - 3 } & Bambara or five fingers* & Green deep lobed leaves and green calyx \\
\cline { 2 - 3 } & Ordinaire or Koor & Red veined leaves and red calyx \\
\cline { 2 - 3 } & Vimto & Red-purple veined leaves and red calyx \\
\hline \multirow{4}{*}{$\begin{array}{l}\text { Vigna unguiculata (L) } \\
\text { Wouge* }\end{array}$} & Red seeds and broad leaves \\
\cline { 2 - 3 } & Blanc & White seeds and narrow leaves \\
\cline { 2 - 3 } & Noir & Black seeds and narrow leaves \\
\cline { 2 - 3 } & Noir-blanc & Black-and-white seeds and narrow leaves \\
\hline Amaranthus L. spp & Vert cliar1 & Narrow light green leaves \\
\cline { 2 - 3 } & Vert clair 2* & Broad light green leaves \\
\cline { 2 - 3 } & Vert foncé & Dark green leaves \\
\cline { 2 - 3 } & Rouge & Red leaves \\
\hline Moringa oleifera Lam & Nébéday & Dark green leaves \\
\hline \multirow{2}{*}{ * Best genotypes for farmers } & \\
\hline
\end{tabular}

Traditional methods of seed conservation have been developed by farmers. Seeds are stored in different types of containers without any chemical product to control pests. Some farmers add wood ash at the top of the container before sealing it. They may also place metal containers in the sun for few days. Polyethylene bags, pieces of cloth, small glass jars filled with sand or metal containers are commonly used for seed storage. Some farmers keep dry pods of cowpea tied to the roof inside their room. The Moringa pods are usually left on the tree and seeds are collected at the time of planting. When seeds are stored for a long time their viability decreases. To avoid this loss of viability, the farmers store the seed between two seasons for no longer than 3 to 6 months. Technical problems may lead to a loss of diversity. Lack of high quality seed can cause many farmers to abandon the production of a species. When pest damage becomes serious in a species, farmers may abandon its production. Decreased viability of seeds that are not well stored is another constraint.

It is also necessary to take into account the socio-economic and cultural factors which can contribute to the loss of diversity. The production and marketing of cowpea leafy vegetables were, for example, positively correlated with the production and availability of pearl millet. This is because cowpea leaves are the preferred green relish consumed together with couscous made from pearl millet grain. Thus any decline in the production and availability of pearl millet will decrease the demand for cowpea leaves and cause a concomitant reduction in its production. Similarly there is a positive correlation between the production and marketing of roselle leaves and the availability of fish in the market. Any decline in the availability of fish will, therefore, contribute to a decrease in the production and storage of roselle seeds. An example of a cultural factor was observed during the seed collection missions in two distant localities (500 km apart) with different ethnic groups, viz. Kaolack and Missira respectively. Both groups believe that 'more than 3 Moringa trees in a house is source of misfortune', because it will increase poverty and cause death in the family.

\section{Marketing}

Selling of leafy vegetable seed is not a common activity in rural areas of Senegal. Generally, farmers exchange gratuitously theirs seeds. However, leaves are commonly sold at the field, in the village, in nearest the city and weekly at a market called 'Louma'. When the leaves are abundant, like during the rainy season, the price per kg could be as low as half of that received during the dry season. Average annual income generated per household by selling vegetable leaves varies from 41 USD in areas where leaf consumption is low to 500 USD where production and sales are higher.

The proportional contribution of leafy vegetables to household income varies from $2 \%$ in areas where the leaves are usually grown together with the main staple crops during rain seasons to $50 \%$ in areas where leafy vegetables are produced as sole crops. Sometimes the contribution of leafy vegetables can reach $100 \%$ of household income. In a recorded case at Mboro a woman was left behind by her husband, who went to look for a job. For a full year the family used only the income generated by selling roselle leaves to acquire enough food and pay the scholarship fees of the children. Other leafy vegetable growers expressed the opinion that 'roselle production can be used against hunger and poverty, it is the 'spice' in the agriculture'. In an area like Mboro production of roselle leaves is so important that during each Muslim annual meeting of the Tidjiania confraternity, the Muslim guide or Marabout requests all members 'to offer prayers for the ladies growing roselle leaves for the development of the production'. In fact, the farmers contribute much to the household income and the funds of the Tidjiania confraternity by using only income generated by roselle leaves.

The potential use of species like Moringa as bioflocculants present additional marketing possibilities for these crops. Methods traditionally employed for water remediation consist of heavy metal removal by chemical coagulation using aluminium and ferric salts (Fatoki and Ogunfowokan, 2002). However, because of the high costs of these methods it is necessary to develop a more cost effective remediation system, particularly in developing countries. Moreover, research findings clearly report the serious drawbacks such as Alzheimer's disease, carcinogenic effects and health problems associated with aluminium sulphate, polyaluminium chloride, polyaluminium sulphate, iron hydroxide, iron chloride, soda ash and synthetic polymers used in water treatment (Morton, 1991). Use of natural coagulants for treatment of water and wastewater in developing countries is an area that is gaining interest. The water-soluble Moringa seed proteins possess coagulating properties similar to those of alum and synthetic cationic polymers. The use of Moringa species for water clarification is a part of African indigenous knowledge. The mechanism of coagulation by Moringa is not well under- 


\begin{tabular}{|c|c|c|c|}
\hline \multicolumn{4}{|c|}{$\begin{array}{c}\text { TABLE } 2 \\
\text { Uses of the most common leafy vegetables found and produced in Senegal }\end{array}$} \\
\hline Species & Variety names & Characteristics* & Uses \\
\hline \multirow[t]{2}{*}{$\begin{array}{l}\text { Hibiscus sabdariffa L. } \\
\text { "Roselle" }\end{array}$} & $\begin{array}{l}\text { Mame Diarra } \\
\text { Bambara or five } \\
\text { fingers }\end{array}$ & Green leaves and green calyx & $\begin{array}{l}\text { Entire leaves (Teumbel) of Mame Diarra or steamed } \\
\text { leaves crashe (Beugeuth) of Bambara are used in } \\
\text { common local dish named "thiebou dieun". } \\
\text { Dried calyx used as condiment or beverage }\end{array}$ \\
\hline & $\begin{array}{l}\text { Ordinaire } \\
\text { or Koor } \\
\text { Vimto }\end{array}$ & $\begin{array}{l}\text { Red or red-purple veined } \\
\text { leaves and red calyx }\end{array}$ & $\begin{array}{l}\text { Leaves are used for “Beugeuth” } \\
\text { Dried calyx used as beverage }\end{array}$ \\
\hline \multirow{2}{*}{$\begin{array}{l}\text { Vigna unguiculata }(\mathrm{L}) \\
\text { WALP } \\
\text { Cowpeas }\end{array}$} & Rouge & Red seeds and broad leaves & $\begin{array}{l}\text { Leaves are prepared in sauce with "couscous” and } \\
\text { seeds are consumed in "Ndambe” (popular food in } \\
\text { Senegal) }\end{array}$ \\
\hline & \begin{tabular}{|l|} 
Blanc \\
Noir \\
Noir-blanc
\end{tabular} & $\begin{array}{l}\text { Narrow leaves and white } \\
\text { (blanc), black (noir) or black- } \\
\text { and-white (noir-blanc) seeds }\end{array}$ & $\begin{array}{l}\text { Leaves and seeds are prepared in sauce with "cous- } \\
\text { cous” }\end{array}$ \\
\hline Amaranthus L. spp & \begin{tabular}{|l|} 
Vert cliar1 \\
Vert clair 2 \\
Vert foncé \\
Rouge \\
\end{tabular} & $\begin{array}{l}\text { Light (clair) or dark ( foncé) } \\
\text { green or red (rouge) leaves }\end{array}$ & $\begin{array}{l}\text { Leaves are prepared in sauce with meal made from } \\
\text { rice }\end{array}$ \\
\hline Moringa oleifera Lam & Nébéday & Dark green leaves & $\begin{array}{l}\text { Leaves are prepared in sauce with “couscous”. } \\
\text { Seeds used against rheumatism and diabetes. }\end{array}$ \\
\hline
\end{tabular}

*For more detail on differences between varieties see Table 1.

stood and different authors have attributed it to existence of proteins and non-protein flocculating agents (Ndabigengesere et al., 1995; Gassenschmidt et al., 1994; Okuda et al., 2001). Bioflocculant is more suitable for enhancing anaerobic granulation than ACGC. Cationic PAM had a less negative effect on sludge.

\section{Uses of leafy vegetables}

Leafy vegetables are used as food and for medicinal purposes. The most common dishes prepared with leafy vegetables are tembeul (which consists of the entire leaves of roselle washed and cooked in water) and beugeuth (a mash prepared from the leaves of roselle steamed and ground using pestle and mortar), both of which are eaten with a popular common local dish, named thiebou dieum, made with rice and fish (Table 2). Other common dishes are sauces made from Moringa leaves (cooked leaves in boiled water with groundnut paste, beef or dried fish and spices eaten with couscous), cooked cowpea leaves eaten together with couscous made from pearl millet grain (mentioned earlier) and amaranth leaves (cooked leaves with palm oil, beef or dried and spices eaten with rice). Tea or common beverages from the dry calyx of red roselle are also consumed in Senegal. Some other uses are also listed in Table 2.

In general sauce made with leaves is eaten without any distinction of age, gender, religion or social status. In ethnic groups where sauce made with the leaves is not eaten, the way in which they cook them is not well known. Leafy vegetable consumption is around $23 \mathrm{~g} /$ person-d in Senegal, which is very close to the average consumption of $24 \mathrm{~g} /$ person'd in Sub-Saharan African countries (Westphal et al., 1985).

Regarding medicinal uses, roselle leaves are used against fever, malaria and heavy cold and also have tonic and appetising properties. Drinking beverage from red calyx mixed with lemon juice is used to control tiredness. Beverage from mixture of red calyx and Adansonia fruits can control diarrhoea. Eating cowpea leaves and seeds can prevent vitamin deficiency. Eating 3 seeds of Moringa per day can control rheumatism after 3 months and diabetes.

\section{Agro-morphological characterisation of roselle accessions}

Roselle accessions were divided into four groups, one with 21 accessions, one with nine accessions, one with three accessions and one with 18 accessions. The number of doubles was 7 in Group 1, 4 in Group 2, 1 in Group 3 and 7 in Group 4, indicating that seed exchange among farmers at local and national levels is common. We found that only 3 of the 19 doubles belong to accessions collected in a specific locality. The remaining 16 contain accessions collected in localities which can be as far as $800 \mathrm{~km}$ apart. This large number of doubles confirms the high level of seed exchange between farmers at village or national level. The level of dissimilarity (63\%) found within the accessions confirmed the high degree of intra-specific variability. Identifying doubles helps to reduce the number of accessions to keep in the gene bank and to obtain a core collection, which is the best strategy for seed conservation (Johnson and Hodgkin, 1999). The Richness Index determined for the Diaobe and Matam markets indicated a high degree of genetic diversity. These two markets are followed, in terms of genetic diversity, by Tamba and Missira markets (Fig. 1). The high genetic diversity of roselle in these markets in Senegal could be related to the role of people who come from neighbouring countries to sell or buy roselle seed at them.

According to their agronomic performance and the preference criteria of farmers, the best genotypes are ps7, ps8, ps24.

\section{Conclusions}

The findings of this study highlighted the importance of indigenous leafy vegetables in Senagalese farming systems practised in rural and peri-urban areas. When producing indigenous leafy 
Figure 1

Intra-species diversity of roselle in the localities visited

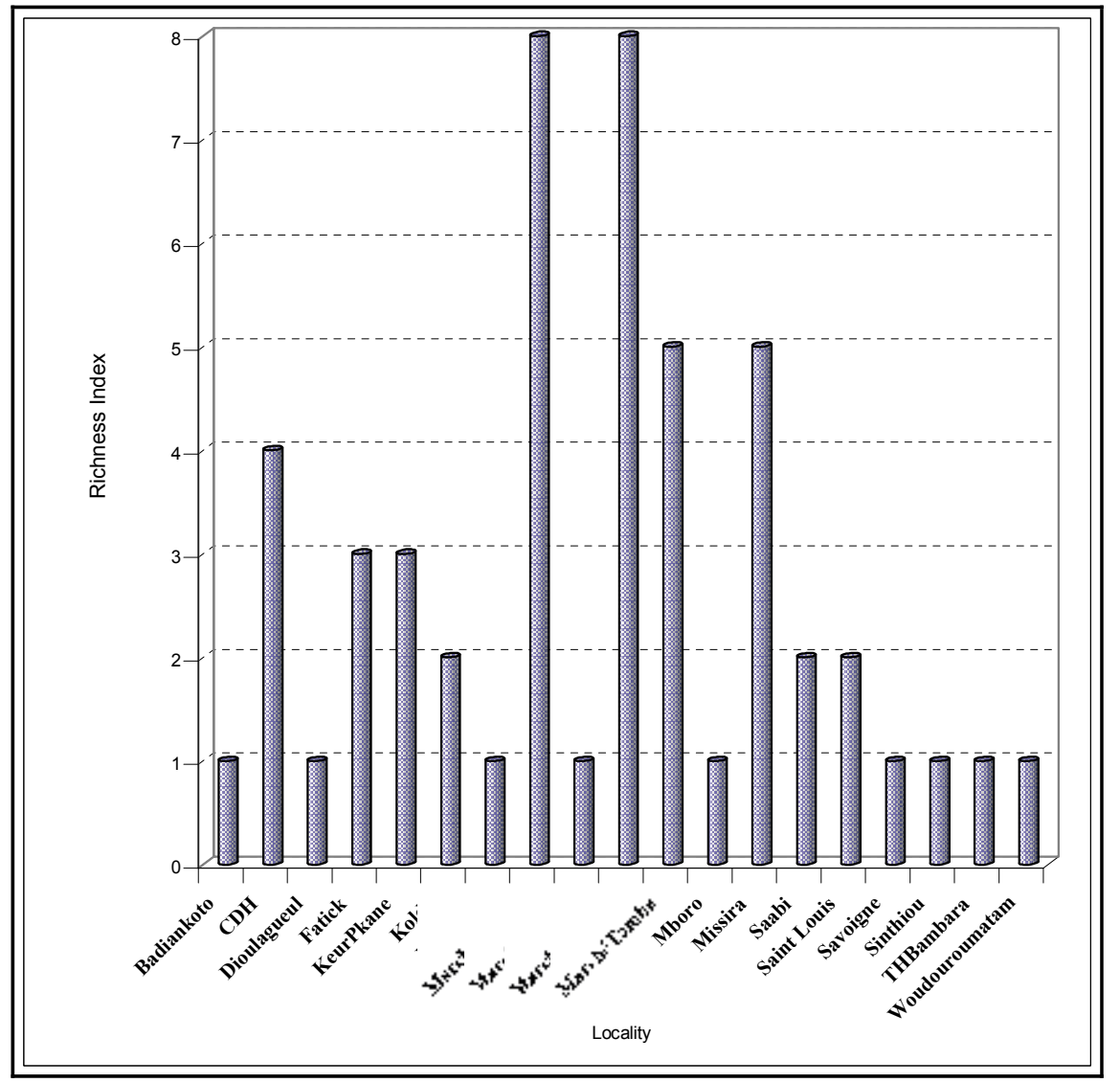

vegetables farmers tend to employ traditional farming practices. They applied fertilisers, but generally at rates lower than recommended. The agro-morphological characterisation of the roselle accessions showed important gene-flows at the village and national levels.

Improvingleafyvegetableproductionrequires development of good farming systems practised for seed and leaf production. A few of the farmers per locality should specialise in seed production. We need to implement reliable seed supply, which requires collecting and characterising biodiversity of the priority species, screening genotypes by using farmers' criteria and also to develop a good seed storage system of germ-plasm. Improving leafy vegetable processing methods, improving local recipes and developing new recipes can help to increase leafy vegetable consumption, and thus enhance the well-being of vulnerable groups living in rural and periurban areas of Senegal.

\section{Acknowledgements}

IPGRI is acknowledged for supporting this research, FAO for funding participation of the senior author in the symposium and the University of Pretoria for inviting him to the symposium.

\section{References}

BENIEST J (ed.) (1987) Guide pratique du maraîchage au Sénégal. CDH-ISRA, BP 3120, Dakar, Sénégal. 83-84.

BRICAGE P (1978) Le bissap (Hibiscus sabdariffa L.), Malvacées. Aspects biologiques. Bulletin AASNS. 64 9-23.

CHADHA ML, ENGLE LM and OLOUCH MO (2000) Vegetable germplasm - conservation and management. A compilation of lecture contents of a training course held at the AVRDC-ARP 26 April
- 1 May, 2000. Organised by AVRDC-ARP SADC Plant genetic Resources Center, Zambia. 207 pp.

DIOUF M, DIOP M, Lô C, DRAMé KA, SèNE E, Bâ CO, GUèYE M and FAYE B (1999) Prospection de légumes feuilles traditionnels de type africain au Sénégal. In: Chweya JA and Eyzaguire P (eds) Biodiversity of traditional leafy vegetables in Africa. Rome, Italy: International Plant Genetic Resources Institute (IPGRI) 111-150.

ELLSWORTH L, DIAMé F, DIOP S and THIéBA D (1992) Le Diagnostic Participatif ou "Participatory Rural Appraisal": astuces et Aides Mémoires pour les Participants d'un Atelier d'Initiation. FRAAP, CP. 13, Dakar-Fann, Senegal. 18-62.

FATOKI OS and OGUNFOWOKAN AO (2002) Effect of coagulant treatment on the metal composition of raw water. Water SA 28 (3) 293-297.

GASSENSCHMIDT U, JANY K and TAUSCHER NH (1994) Isolation and characterisation of a floculating protein from Moringa oleifera Lam. Biochemica et Biophysica Acta 1243 477-481.

GENTLEMAN R and IHAKA R (2002) Statistics Department of the University of Auckland. In: Verzani J (ed.) Simple R-Using $R$ for Introductory Statistics. Nairobi, Kenya IPGRI-SSA 109.

GRUM M (2002) clustering for Plant Genetic Resources: Application in R Made Simple. IPGRI-SSA, Nairobi, Kenya. 1-19.

IPGRI (2001) Design and Analysis of Evaluation Trials of Genetic Resources Collections. IPGRI, Via dei treenari, 472/a, 00057, Maccarese, Rome, Italy. 53 pp.

JOSHI A and WITCOMBE JR (1996) Farmer participatory crop improvement. II. Participatory varietal selection, a case study in India. Exp. Agric. 32 461-477.

MORTON JF (1991) The Horseradish tree, Moringa pterygosperma (Moringaceae) - A Boon to Arid lands. Econ. Bot. 45 318-333.

NDABIGENGESERE A, NARASIAH KS and TALBOT GB (1995) Active agents and mechanism of coagulation of turbid waters using Moringa oleifera. Water Res. 29 703-710.

OKUDA T, BAES AU, NISHIJINA W and OKUDA M (2001) Coagulation mechanism of salt solution-extracted active component in Moringa oleifera seeds. Water Res. 35 830-834. 
QUID (Questionnaire Unifié des Indicateurs de Développement) des Enquêtes Sénégalais Auprès des Ménages (ESAM-II) (2001) Document de Stratégie de Réduction de la Pauvreté Dakar, Sénégal: (DRSP). 64 pp.

WATSON JW and EYZAGUIRE PB (eds.) (2002) Home gardens and in situ conservation of plant genetic resources in farming systems. Proc. $2^{\text {nd }}$ Int. Home Gardens Workshop. 17-19 July 2001, Witzenhausen, Federal Republic of Germany. 3-9.
WANG JING-SONG, HU YONG-YOU and WU CHUN-DE (2005) Comparing the effect of bioflocculant with synthetic polymers on enhancing granulation in UASB reactors for low-strength wastewater treatment. Water SA 31 (2) 177-182.

WESTPHAL E, EMBRECHTS J, FERWERDA J.D, VAN GILSMEEUS HAE, MUSTSAERS HJW and WESTPHAL-STEVELS JMC (1987) Les cultures potagères: Cultures vivrières tropicales avec référence spéciale au Cameroun. 321-463. 